\title{
LANGUAGE RIGHTS IN EDUCATION IN SOUTH AFRICA
}

\author{
D. Mkhize*
}

Faculty of Education

e-mail: 25759663@nwu.ac.za

\section{R. Balfour*}

Deputy Vice Chancellor (Teaching and Learning)

e-mail: Robert.balfour@nwu.ac.za

*North West University

Potchefstroom, South Africa

\section{ABSTRACT}

Realisation of multilingual education as a right has remained a controversial issue in South Africa. This is despite the Constitutional and legislative frameworks that support multilingual education. While the controversy undermines linguistic diversity in educational institutions in general, as suggested by the exclusion of African languages in the curriculum in some primary schools, it is in the curriculum of most institutions of higher learning where this linguistic diversity is undermined. Despite this bleak picture, some studies report promising trends regarding attempts at promoting multilingual education in some of these institutions. The article concludes by encouraging the universities to interrogate the language ideologies that underlie the language policies and implementation of the policies in the institutions of higher learning, and how these promote or infringe the language rights of students.

Keywords: higher education; language ideology; language policy; language rights; multilingual education

\section{INTRODUCTION}

Despite the fact that the majority of people in South Africa speak languages other than English and Afrikaans, these languages-English, in particular, and Afrikaans, to a lesser extentcontinue to dominate official public domains. The continued hegemony of these languages undermines the language rights of other citizens as enshrined in the Constitution of the Republic of South Africa (1996) and other legislative frameworks. In education, this hegemony circumscribes additive multilingualism as promoted in the Constitution, Language-inEducation Policy (LiEP) (Department of Education 1997), Language Policy for Higher Education (Department of Education 2002) and other legislative frameworks. To discuss multilingual education as a right in higher educational institutions this article is structured into 
five sections. In the first section we reflect on the Constitutional principles and language-policyin-education frameworks regarding multilingual education inclusive of schooling since the foundations of literacy are developed there first. The second section discusses language ideologies (Liddicoat and Taylor-Leech 2015) that underpin university language policies which leads to the third section (the methodological approach) in which the rationale for the selection of five universities is provided. Section four describes the universities selected in terms of four themes concerning access to, use of, and support for African languages in these settings.

The continued hegemony of English and Afrikaans in schools has consequences throughout the education sector for African-language speaking students (Fleisch 2008; Moloi and Chetty 2011). Similarly, at higher education level, academic literacy requirements in English remain challenging and have an impact on throughput rates (Ndebele et al. 2013), attitudes (Nkosi 2014), classroom interaction (Madiba 2014; Makalela 2015) and policyimplementation (Balfour 2010; Turner and Wildsmith-Cromarty 2014). The consequences is that by the time South African children access universities as students few have achieved what Widdowson (2001) would term 'coordinate bilingualism', where a person can express or understand complex meaning in more than one language in the four basic literacy skills. The reason for this is, as noted by Barnes (2004): the education system in South Africa has not offered sustained learning as well as acquisition opportunities for the majority of the population in more than one language throughout schooling. In part this problem occurs in school because teachers are trained for instruction in English or Afrikaans, but also in part because, in higher education, African languages do not have histories as academic languages in higher education. Across the sector there is little awareness of translanguaging pedagogies, or awareness of how to teach the languages and content areas simultaneously. A further challenge is, as a result of historical neglect, is a lack of coherence as regards terminology, spelling and phonology within African languages (Webb, Lafon and Pare 2010).

The choice of English as a lingua franca or MoI is tenuous: the number of mother tongue speakers (SAIRR figures in 1999 showed that isiZulu, isiXhosa and Afrikaans were the three largest language groupings in South Africa) (SAIRR 1999). SAIRR figures in 2014 (SAIRR 2014) reported that the numbers of South Africans identifying as English home language speakers increased from 3.3 million to 3.9 million in 2013, but constituted 11 per cent of the population in both the 1999 and 2013 surveys.

With reference to higher education Tait (2007) notes that the development of African languages between 1995-2005, did not occur first because policy provision was vague, and did not compel universities to develop African languages in higher education programmes. A 
second reason in the early years was because not enough planning went into African languages development as languages of learning in higher education (The Development of Indigenous African Languages as Mediums of Instruction in Higher Education, Ministerial Committee's Report) (Department of Education 2004). Thirdly, the academic success of students, educated through English, was not adequately supported (Phillips 2004) throughout schooling after the Foundation Phase. In other words, whilst English might be the language of instruction in many schools, it is seldom taught as language in other content areas. The evidence suggests that educating students in a language that they do not understand, or which is not their home tongue, increases the risk of failure (Fouche 2009). Even though parents choose English because of its associations with social mobility, economic opportunity and education quality, the choice is an ambiguous one in the context of South Africa's language rights (despite these being founded on sound language acquisition principles).

However, in order to understand language rights in multilingual education in South Africa, we begin by critically evaluating the language provisions in the Constitution and other legislative frameworks.

\section{LANGUAGE RIGHTS, CONSTITUTIONAL AND OTHER LEGISLATIVE FRAMEWORKS}

Contrary to the developed world where language rights are often intended to protect languages spoken by the minority groups (Skutnabb-Kangas 2006; May 2005), in Africa, including South Africa, language rights are aimed at protecting languages spoken by the majority of the people against dominant languages, such as English, French, Portuguese, and sometimes other dominant African languages (Docrat and Kaschula 2015; Namyalo and Nakayiza 2015). In the former case, the debate tends to be framed from the language ecology perspective, whereby the basic argument that languages, endangered languages in particular, need to be supported through inclusive policies in order for them to live and thrive (Hornberger 2002; Mühlhäuser 1996). In the latter instance, specifically in the case of South Africa, language rights are framed from a legal perspective as evidenced by the articulation of language rights in the Constitution and other legislative frameworks.

Sections 6, 9, 29, 30, 31 and 35 of the Constitution describe language rights in the public domain. Section 6(1) affords official status to 11 languages, 9 of which are indigenous African languages. In Section 6(2) the state is ordered to 'take practical and positive measures to elevate the status and advance the use of these languages' (Constitution of the Republic of South Africa 1996, 4). Section 29 (2) adopts this flexible approach to language use, stating that 'everyone 
has a right to receive education in the official language or languages of their choice in public educational institutions where that education is reasonably practicable' (Constitution of the Republic of South Africa 1996, 15). We concur with Docrat and Kaschula (2015) that while phrases such as 'practical' and 'reasonably practical' allow institutions to tailor language policies to their needs, these phrases open the possibility of the continuation of old practices. The Honourable Justice Sachs as cited in Perry $(2004,131)$ described institutional language policies as 'messy, inelegant, and contradictory', as most institutions tended at first to resort to English and Afrikaans, and thus undermine the promotion of multilingualism as promulgated in Language in Education Policy (Department of Education 1997) and Language Policy for Higher Education (Department of Education 2002).

Arguably, the practicality consideration that is also articulated in these two policies encourages some school governing bodies and universities' language structures to adopt an ambivalent attitude, and in extreme cases, a hostile attitude towards African languages, claiming to be protecting the language rights of the institutions on 'academic' grounds (a factor noted in higher education, see Parmegiani and Rudwick (2014) and schools, see Smit (2007).

In higher education various organisations, for example, Afriforum in 2015 (Du Toit 2016) have litigated universities about changes to their language policies concerning the perceived diminishment of Afrikaans. It should also be acknowledged that there has been at national level an absence of political will to really support languages-education towards languages-access in all education sectors. To date PanSALB has failed to develop a visible plan and profile for language development in South Africa (SA Government News Agency 2016). The absence of credible regulatory control, a realisable mandate and capacity to deliver on its accountability aims, has weakened PanSALB.

However, to understand the continued domination of English in all institutions of higher learning one has to comprehend the ideologies that underlie the policies and practices in these institutions. Ideologies about language, language policies and use are linked to the sociohistorical and political processes (Garcia 2009). In Plüddemann’s $(2015,188)$ words, ‘policy (a text documenting language rights - own emphasis) is more than text; it is a process that carries an ideological load, and is subject to interpretation by competing interest groups in ways that reflect power relations between them'. In the next section, therefore, we discuss language ideologies, showing how these ideologies, as informed by the historical and socio-political processes shape the language rights debate and the realisation of these rights in higher education institutions. 


\section{LANGUAGE RIGHTS AND LANGUAGE IDEOLOGIES}

Language ideologies are defined as a set of beliefs, attitudes, values, and cultural orientations about ways in which language should be understood and used in society (Blommaert 1999; Pavlenko and Blackledge 2004). In this respect, ideologies are social constructions and motivate actions that support or constrain legitimatization of some languages over others in a hierarchy (Namyalo and Nakayiza 2015; May 2015, 358). Of significance, language ideologies are produced and reproduced through discourse; that is, systems of power-relations that legitimatize or restrict what people 'say and do not say, and do and do not do' (Blommaert 1999, 10), and 'how and by whom it should be said and whether it can be heard' (Makoe and Mckinney 2014, 659); and we may add, in what language or languages. So ideologies are connected to a politics of language in which power relations, social structures and groups coalesce around issues of identity, ethnicity and gender (Garcia 2009, 84; Namyalo and Nakayiza 2015, 412).

Monolingual ideologies can be traced to the European Enlightenment history that was characterised by the view of one-language one-nation where a national language was directly associated with national identity (Liddicoat and Taylor-Leech 2015; Pennycook 2010). It is this ideology that the National Party, which was dominant politically in the apartheid era, adopted when it came to power in 1948, linking language to national/ethnic identity (the obvious example being Afrikaans) (Heugh 2016). Similarly, individual African languages became synonymous with the corresponding ethnic identities This segregationist ideology was consistent with the separate development policy of the apartheid-era National Party; it met with resistance from the liberation movements, which viewed English as the language for liberation (Alexander 1989), and thus unwittingly privileged English at the expense of African languages (Balfour 2003).

The tensions between segregationist (for example, the justification of developing African languages only for those students interested in them) and the assimilationist ideologies (for example, the justification of English as the only MoI) continue to exist in the post-apartheid South Africa despite Constitutional provisions in which all the official languages are supposed to enjoy parity of esteem and be treated equitably. What seems to be oblivious to the proponents of these ideologies is that both ideologies infringe the language rights of African-language speaking students. Furthermore, neither of these ideologies take cognisance of the fact that in the $21^{\text {st }}$ century linguistic fluidity and diversity is increasingly becoming a norm, in part, due to globalisation and urban migration (Blommaert 2010; Pennycook 2010). In addition, language 
can no longer be unidirectionally connected to identity (Garcia 2009; Makalela 2015; Mkhize 2016).

As Hornberger (2002, 27) suggests, in order to understand linguistic and ethnic complexities of students in the $21^{\text {st }}$ century and how these complexities can be addressed, we need to 'open up ideological spaces and fill in implementational spaces' through multilingual language policies which promote linguistic and ethnic diversity as a means for nation-building. She adds that the ideologies that underpin these policies have no room for assimilationist or homogenizing discourses (and we may add, segregationist discourses); instead, such policy discourses embrace multilingualism as a new world of possibilities. However, these possibilities are not without ideological contradictions and paradoxes as educational institutions wrestle with diversification in their policies (Hornberger 2002; Liddicoat and Taylor-Leech 2015).

In South Africa nowhere are these contestations evident than in the opportunities and challenges posed by implementation of multilingual policies in higher educational institutions. This is despite the ideological spaces that have been opened up by the provisions in the Constitution and other legislative frameworks regarding multilingual education, specifically the promotion of African languages as academic and communication languages at the universities. Some universities show more commitment to the promotion of African languages than others (Turner and Wildsmith-Cromarty 2014; Maseko 2014; Pillay and Yu 2015). Whilst controversial, we argue that an absence of commitment results in the violation of the language rights of African-language speaking students, and also promotes continued hegemonic assimilationist and segregationist ideologies. Not only do these ideologies have a negative impact on the academic performance of African-language speaking students, they violate the language rights of these students, as they also derail social cohesion, which is a cornerstone for a successful democracy. This argument has many facets but perhaps the most compelling is that there is incontrovertible evidence of causality between poor performance in schools and what Ndebele et al. (2013) has described as the sluggish and inefficient higher education sector. Unintentional consequences of low literacy and inadequate attention to language development, have been the high drop-out rates associated with schooling (Shepherd and Van der Berg 2015) and poor throughput rates associated with the university sector (Bozolli 2015). To sum up so far: previous sections demonstrate that studies in schools confirm that English remains underdeveloped as a language of instruction, and by comparison, African languages even more so. At higher education institutions the under-development of English is evident in low levels of academic literacy in English. Taken jointly, there are two points to be made. First, school-based 
and university-based research points to the deleterious consequences of the same problem: inadequate development of the home language makes for difficult acquisition of the target language (and its associated literacies as noted by Cillié and Coetzee 2013) and further constrains efforts of students to make the transition (Boughey 2013) from school to the high literacy levels required for university studies through English (Cliff 2015). Second, new research shows that where formal provision (development, support, use) is made for the development and use of African languages for teaching and learning, rich pedagogic and research opportunities arise for students and academics alike.

A comprehensive study undertaken by Tait (2007) found much evidence for the diminishment of Afrikaans in higher education, but no evidence yet for the promotion of African languages for higher learning purposes. Some ten years later new developments to revitalise African languages have come to the fore (Hibbert and Van der Walt 2014) and the policy landscape itself is shifting.

\section{LANGUAGE POLICY CHANGE AND IMPLEMENTATION: A METHODOLOGICAL NOTE}

This section describes aspects of the language policies of the selected universities, how these universities implement the policies, and how ideologies underpinning these policies support and/or delimit the realisation of students' language rights in five universities; the University of KwaZulu-Natal (UKZN), the University of Cape Town (UCT), Stellenbosch University (SU), Rhodes University (RU), and the University of Pretoria (UP). Such an analysis is timely. The criterion used for selecting five these universities is that they do use more than one language as a MoI and may thus be regarded as exemplars of practice as encouraged within this new landscape. At UKZN, Rhodes and UCT, English remains the primary language for learning, teaching, and research, but within the last seven years isiXhosa and isiZulu have been introduced. On the other hand, at SU and UP Afrikaans was the primary language of instruction, but in recent years English has become the primary language of instruction, with Afrikaans being supported where demand merits it, and a conscious shift to bilingual education, with the introduction of isiXhosa into selected programmes at SU, for example. Data were drawn from the language policies of these universities and some studies on the promotion and challenges of multilingualism in these universities (Madiba 2014; Nkosi 2014; Pillay and Yu 2015; Turner and Wildsmith-Cromarty 2014; Maseko 2014).

Questions that guided our analysis are derived also from Lo Bianco's (2004) criteria for policy evaluation. Lo Bianco $(2004,2)$ argues that policy can be evaluated on the basis of 
whether it draws on a body of research, it takes note of existing resources available to be used towards realisation, it is just and humanitarian, and addresses national interest, without compromising the needs of groups in a country. These four criteria are a useful means of influencing our questions concerned as they are with language rights realisation. Is there a structure that is specifically designated to promote multilingualism? Does the university strive towards promoting the development of African languages for academic purposes, and how? Does the university support the development of terminology (Pare 2007) and other linguistic resources in African languages for academic purposes? Does the university offer vocationaloriented courses in African languages? Does the university teach African language courses to non-speakers of African languages? The discussion to follow is structured around the following themes: African languages as languages for learning, teaching, and research; African languages in professional fields for professional use, and African languages as language courses for nonmother tongue speakers.

\section{AFRICAN LANGUAGES AS LANGUAGES FOR LEARNING, TEACHING, AND RESEARCH}

The Language Policy for Higher Education (Department of Education 2002) stipulates that each university should formulate a language policy that strives towards the development of languages other than English and Afrikaans for academic purposes. The universities have heeded this call in varying degrees, with some showing more commitment than others (Madiba 2014; Nkosi 2014; Turner and Wildsmith-Cromarty 2014). For example, the first part of section 3(2) of the UKZN (Language Policy of the University of KwaZulu-Natal 2007) language policy states: 'The University will develop isiZulu for use in instruction as part of a medium- to longterm strategy to promote bilingualism'. Section 4(1) stipulates: 'The University shall pay particular attention to curriculum development in English and isiZulu'. Similarly, UCT (Language Policy for the University of Cape Town 2003) language policy states:

To further the objective of the promotion of multi-lingual awareness and proficiency, all academic programme convenors and teachers will be required, with the aid of language and literature departments ...

At UKZN the use of both isiZulu and English in the Foundation Phase programmes, where the programmes are taught and assessed in isiZulu and English, is an indication of the implementation of the policy. In addition, UKZN has a dual-medium postgraduate Bachelor of Education Honours (B.Ed. Hons.) degree, where the core modules are taught in English, and the specialisation modules are offered either in isiZulu or English. That the students who are 
taking specialisation modules in isiZulu are allowed to write a research project in isiZulu shows that the University's commitment goes beyond promoting isiZulu to the status of being the language of learning and teaching, but it is also striving to make it one of the languages for research. Clearly, the use of isiZulu as a MoI and a language for research challenges inequitable power-relations between English and this language, and most importantly, the ideology that before African languages can be used for academic purposes, they have to be fully developed. This argument underscores the significance of accelerated speed with which measures for developing African languages should be taken in order to ensure that the language rights of African-language speaking students to access good quality education are not infringed.

Language development at SU concerns isiXhosa. Whilst at UKZN isiZulu is a compulsory subject for the development of professional competencies in the Faculty of Health Sciences as well as the Faculty of Education, at SU provision is similarly made for isiXhosa (Language Policy for Stellenbosch Policy 2016, section 7.5.4): 'In certain programmes, isiXhosa is already used with a view to facilitating effective learning and teaching, especially where the use of isiXhosa may be important for career purposes'. And, like UKZN and UCT, SU has a Language Centre which focusses not only on the provision of short courses, but also on terminology development (in the form of glossaries in numerous subjects). It is important to note the collaborations within the sector in terms of terminology development (for example, the collaboration between UKZN and the University of Zululand in relation to isiZulu, and the collaboration between the Lingua Project and the University of Birmingham for tshiVenda, see Madiba 2004; or the NWU and UP collaboration as noted by Roux and Bosch 2006).

Though bilingualism has yet to formally feature in language policies in South Africa (with the exception of UKZN), there are already promising initiatives in the form of the bilingual degrees in Journalism (at Rhodes University) and the bilingual BA degree in communication and media as long-offered at the University of Limpopo.

What is noticeable in relation to the development of African languages at UKZN, SU, Rhodes and UCT is that dedicated responsibility and resources have been placed at the disposal of centres and departments committed to help realising the universities' aspirations in various disciplines, but that not all five universities have advanced to the same extent. At UKZN the language policy (Language Policy of the University of KwaZulu Natal 2007), and specifically section 3(3), states: 'The promotion of isiZulu for use in instruction will require the development of dictionaries and other teaching and learning materials'. The lexicography unit at UKZN, therefore, develops academic terminologies in isiZulu for use in modules offered in the School of Education, and School of Applied Human Sciences, for example. 
Likewise, through the Multilingualism Education Project (MEP), UCT is working towards developing African languages for academic purposes by developing literacy concepts in all the 9 African languages in disciplines, such as Law, Economics, and Statistics. This multilingual concept literacy project uses a translanguaging approach. In translanguaging the languages of bilinguals/multilinguals are not kept completely separate from one another; rather, they may be used along one another to ensure that users understand the content or message (Garcia 2009; Garcia and Wei 2014). To accommodate this linguistic flexibility, the online resource, Online Learning Environment, also known as Vula, which in the Nguni languages means open, supposedly because it opens doors for meaningful learning by African-language speaking students, allows users to comment on the quality of the translation. This deepening of conceptual understanding extends to tutorials, though we acknowledge that this is small step in addressing the legacy of colonial language policy in South Africa.

In both UKZN and UCT alternating languages within the same tutorial or lesson is formally allowed. Makalela (2015, 212) suggests, with reference to a student interviewed in a study on translanguaging, that this enhances learning: 'I realize that I was able to think in Sepedi, in English, and in other languages I know. I had to know an idea three or four times. Sometimes I find that there are no words to explain from one language. My mind was challenged and I think that is why I concentrated in this class and passed the course so well'. In addition to enhancing conceptual understanding, use of all students' linguistic resources creates a space for them to be active language policy actors (Plüddemann 2015, 193), which supports language planning from below (Alexander 1989), which, in turn, opens up the ideological and implementation spaces (Hornberger 2002).

Unlike at UKZN and UCT, where there is a noticeable opening up of implementation spaces regarding the promotion of African languages for academic purposes as promulgated in the language policies of these universities, at SU and UP the language policies seem to focus on the accommodation of English as an academic language on par with Afrikaans, together with the introduction of isiXhosa at SU. At SU, isiXhosa is promoted also through information and communication technology (ICT) strategies, as shown in this quote from section 7.1.6 of the language policy:

In addition to lectures, based on students' needs and practicability, SU provides a variety of ICT-enhanced learning strategies, including podcasts and vodcasts of lectures, which are made available to students in Afrikaans, English and, in some cases, in isiXhosa for the further reinforcement of concepts and for revision purposes (Language Policy for Stellenbosch University 2016, 6).

A different situation obtains with UP with the adoption of its new language policy in 2016 in 
which the inclusion of English as an academic language is emphasised alongside Afrikaans (Language Policy for the University of Pretoria 2016, Clause 2; 3.3). The UP Language Policy grants parity of esteem to English and Afrikaans in the following respects: 'In conducting its business, the University shall use two official languages, namely Afrikaans and English with Sepedi as a third language of communication' (Language Policy for the University of Pretoria 2016, Clause 3.1). This is affirmed in Clause 3.6 'There is to be no discrimination against any staff member or student who has command of only Afrikaans or of only English or of only these two languages'. Parity is an accurate description in relation to the Clause on non-discrimination between two languages regarded as equal by UP. Mention of Sepedi is absent. One could argue that the omission in the case of UP is a delimitation of the language rights of the students who speak these languages. Thus whilst English enjoys parity of esteem, with Afrikaans in the new UP policy, the development of Sepedi is not addressed.

\section{AFRICAN LANGUAGES IN PROFESSIONAL FIELDS FOR PROFESSIONAL USE}

In addition to striving for academic use of African languages, UKZN, SU and UCT have introduced isiZulu and isiXhosa respectively in professional or clinical-based modules to help students learn these languages for professional purposes. For example, the College of Health Sciences in UKZN has made it compulsory for all first-year non-isiZulu speaking students to take a course in isiZulu for professional use. Similarly, the medical school at UCT has compulsory clinical-based modules in isiXhosa, Afrikaans, and English. On-site clinical examinations are conducted by specialists competent in these languages and in the clinical field. Like at UKZN, at SU isiXhosa has been introduced in selected programmes, but there are no reports that UP (Language Policy for the University of Pretoria 2010) has introduced an African language in professional or clinical-based modules, though English became the primary language of instruction according to Anna-Retha Bouwer, UP spokesperson (Gqirana 2016). One has to bear in mind though that both policies at SU and UP were accepted in mid-2016. In the 8 months between policy adoption and the writing of this article the shift from policy to implementation occurs at the level of the media and popular discourse (Gqirana 2016). It will take, judging from the Rhodes and UKZN experience, approximately five years for translanguaging classrooms to become the norm.

The teaching of African languages for professional purposes at UKZN, SU and UCT not only promotes multilingualism, but provides the space for students and academics to access language rights with support and confidence. When the students graduate and go to work in the communities where these languages are spoken, they will mostly speak in the language or 
languages that the communities understand, and this will increase opportunities for them to offer quality healthcare, another right which is enshrined in the Constitution (see section 27). This is an example of how rights interact with one another to ensure a better life for all.

\section{AFRICAN LANGUAGES AS LANGUAGE COURSES FOR NON-MOTHER TONGUE SPEAKERS}

Besides the measures that UKZN has taken to advance the use of isiZulu for academic and professional purposes, in 2014 the university introduced isiZulu as a compulsory subject for all non-mother tongue speakers of isiZulu across all disciplines-the only university to have such a policy. Students who are exempted from this are those who speak one of the Nguni languages or who took isiZulu as a first or additional language in Grade 12. That these students are not taking a language outside the Nguni language cluster is a missed opportunity. For example, taking a language from a Sotho language cluster would expose them to a language spoken by their peers, and thus increase not only their linguistic resources, but promote mutual understanding and respect. In this sense, language rights should go beyond simply having one's language rights respected, but it should also entail respecting other people’s language rights by being willing to meet them halfway. Furthermore, from a scholarship perspective, while linguists and language teachers confirm that the introduction of a second language as the language of instruction often complicates the progress made by the learner (lending unwitting credence to the arguments that English, for example, should be introduced even earlier in the school curriculum), there is broad agreement that knowledge of a second language provides cognitive, social and other advantages to learners, (see Bialystok 2004; Bialystok, Majumber and Martin 2003; Garcia 2009). Not least of these advantages is intercultural awareness - an essential skill associated with the globalised world.

UCT (and also Rhodes as noted later) introduced isiXhosa courses to non-mother tongue speakers of this language under the banner Masithethe isiXhosa, which means 'Let's speak isiXhosa'. However, this policy is not as progressive as that of UKZN because students are not necessarily compelled to take these courses, except those who are in the isiXhosa discipline.

Learning African languages by non-African speaking students and staff, and encouraging African-speaking students and staff to learn an African language outside the language cluster of the language they already know will help to break down linguistic and identity boundaries. These boundaries are increasingly becoming more permeable in our multilingual society, in part, due to translocal and transnational migration, as one of the students taking an African language course at the University of the Witwatersrand indicated: 
The class discussion really took me by surprise. I realise that Nguni and Sotho language have more cultural practices in common than I had thought when I first came into this class. One thing I recall very well was when we found out that when an unmarried man dies, his coffin does not go out through the door, but it is carried through the Veranda wall. How can this be the same in my language and in Sepedi language? I like the way we compared these languages when we talked (Makalela 2015, 211).

Beyond this, communicating in other people's languages may be viewed as consistent with the Constitution in that it creates a space that has the potential to dismantle 'hierarchization of languages' May (2015, 358), and thus affords all languages some level of equality, at least at a communication level. In this respect, everyone's language rights are respected.

At Rhodes University the language policy as approved by the Council in 2005, provided the impulse for the Department of African Languages to reinvigorate and position itself to offer isiXhosa for research, teaching and learning purposes (Maseko 2014, 39). Rhodes University also leveraged funding to support the research and development of course and other materials, and then also leveraged networking with other universities (like UCT, Rhodes, and UKZN) to collaborate on language development nationally.

In summary, we argue that the policies and the implementation of the policies at the selected universities discussed above are opening up 'ideological and implementation spaces' (Hornberger 2002, 27). That is, they are widening our understanding of multilingualism, the ideologies that underpin the different faces of multilingualism, and most importantly, how these support and/or constrain the language rights of students. For example, one view is that of multilingualism as a series of bounded separate languages or 'parallel monolingualism' (Garcia and Wei 2014). Widdowson $(2001,10)$ described an implication of this perspective when he coined the term 'permissive pedagogy':

which allows for, even encourages, the learners' engagement of the L1, but again makes no acknowledgement of its existence in the design of the instruction itself. Monolingual teaching is justified in this case on the grounds that input in the L2, so long as it is comprehensible, will automatically activate learning.

Another perspective entails seeing multilingualism as an array of linguistic resources and repertoires that cannot be put into clearly demarcated 'linguistic boxes' (Makalela 2015). An example is translanguaging. In Garcia's (2009, 141) words, translanguaging is 'the act performed by bilinguals of accessing different linguistic features of various modes of what are described as autonomous languages'.

Unlike 'parallel monolingualism' (Garcia and Wei 2014) which is often informed by monoglossic ideologies of language, in translanguaging heteroglossic ideologies underscore linguistic fluidity and flexibility (Pennycook 2010; Makalela 2015). Accommodating different 
forms of multilingualism and ideologies underpinning multilingualism may cause some tensions. However, this is not unique to South Africa; ideological tensions 'have come to exist in parallel in contemporary educational discourses around the world and may be simultaneously present in many societies' (Liddicoat and Taylor-Leech 2015, 2). In this study, one consequence of monoglossic ideologies is that they may restrict the realisation of the language rights of students, especially those with hybrid language practices, which, for the most part, are Africanlanguage speaking students from urban and township areas. On the other hand, heteroglossic ideologies may create a space for the respect of the linguistic rights of these students. Thus when institutions implement multilingual language policies, they should be aware of how ideologies underpinning the policies may encourage support or undermining of the promotion of multilingualism, and how this may affect students' access to high-quality learning and promotion of equitable practices that protect all students' language rights.

\section{CONCLUSION}

In 2007 Tait concluded from his analysis of South African language policy documentation that, in general, South African universities 'are not yet prepared to take the risk of using any of the South African languages apart from English and Afrikaans as media of instruction'. The failure to promote multilingualism also hampers the creation of an inclusive institutional environment advancing tolerance and respect for diversity ' ... [and that] policies do not adequately meet the needs of the country and Constitution' (Tait 2007, 179).

Much has occurred since then. The use of English been recently touted in the media as a means securing wider access, but the issue, when it comes to an assessment of Constitutional rights, goes not to the point of access to education, but rather the right to a reasonable prospect of success through education. This nuance allows one to consider the extent to which language policies enable students to achieve a reasonable prospect of success, having already secured access through meeting the entry requirements of higher education institutions. As noted earlier, the links between underperformance in schooling and poor throughput rates for black students especially (for whom English remains a second or third language) at universities, are obvious. The commitment to developing African languages as a viable means of enabling success in higher education remains equally compelling. Arguments for retaining only two of South Africa's eleven languages contradict a fundamental human right for the vast majority of South African citizens who remain not only entitled to the right, but expectant of higher education's commitment to enable academic success through it. 


\section{REFERENCES}

Alexander, N. 1989. Language policy and national unity in South Africa. Cape Town: Buchu Books.

Balfour, R. J. 2003. Post-Colonial twilight: English as a failed lingua franca. English Academy Review (19): 20-32.

Balfour, R. J. 2010. 'The Long Walk ...'. In A Special Issue on Languages in Higher Education in South Africa, ed. R. J. Balfour, ed. Language Learning Journal 37(3): 249-251.

Barnes, L. 2004. Additive bilingualism in the South African Language-in-Education Policy: Is there proof in the pudding? Alternation Special Issue on Language and Changing Contexts: Sociolinguistic Perspectives 11(2): 44-61.

Bialystok, E. 2004. The impact of bilingualism on language and literacy development. In The Handbook of Bilingualism, ed. T. K. Bhatia and W. C. Ritchie. Malden, Oxford \& Carlton: Blackwell Press.

Bialystok, E., S. Majumber and M. M. Martin. 2003. Developing phonological awareness: Is there a bilingual advantage? Applied Psycholinguistics 24(1): 27-44.

Blommaert, J. 2010. The sociolinguistics of globalisation. Cambridge: Cambridge University Press.

Blommaert, J. 1999. Language ideological debate. Berlin: Walter de Gruyter.

Boughey, C. 2013. What are we thinking of? A critical overview of approaches to developing academic literacy in South African Higher Education. Journal for Language Teaching 47(2): 25-42.

Bozzoli, B. 2015. On my mind: Stuck in the past. Opinion. Financial Mail. 13 April. http:// www.financialmail.co.za/fm/2015/04/09/on-my-mind-stuck-in-the-past (accessed 8 September 2015).

Cillié, K. and M. Coetzee. 2013. Student se persepsies oor die moontlike oordrag van akademiese geletterheidsvaardighede na ander leerkontekste. Per Linguam 29(1): 1-14.

Cliff, A. 2015. The National Benchmark Test in Academic Literacy: How might it be used to support teaching in higher education? Language Matters 46(1) 3-21.

Constitution of the Republic of South Africa. 1996. http://www.gov.za/documents/ constitution/constitution-republic-south-Africa-1996-1 (accessed 10 November 2016).

Department of Education. 1996. South African Schools Act. https://www.gdeadmissions.gov.za/ Content/Files/SchoolsAct.pdf (accessed 4 November 2016).

Department of Education. 1997. Language in Education Policy. http://www.education.gov.za /Documents/policies/LanguageEducationPolicy1997 (accessed 14 November 2016).

Department of Education. 2002. Language Policy for Higher Education. Pretoria, Government Printing Works.

Department of Education. 2004. The Development of Indigenous African Languages as Mediums of Instruction in Higher Education. Ministerial Committee's report to the Minister of Education. Pretoria: Department of Education. http://www.education.gov.za/content/documents/632.pdf (accessed 28 November 2016).

Docrat, Z. and R. H. Kaschula. 2015. Meaningful engagement: Towards a language rights paradigm for effective language policy implementation. Southern African Linguistics and Applied Language Studies 5(1): 1-9.

Du Toit, N. 2016. Language: Where are we now? Bonfire Stellenbosch. http://www.bonfiire.com/ stellenbosch/2016/02/language-where-are-we-now/ (accessed 30 March 2016).

Fleisch, B. 2008. Primary education in crisis: Why South African school children underachieve in reading and mathematics. Cape Town: Juta \& Co.

Fouche, I. 2009. Improving the academic literacy levels of first-year natural sciences students by means of an academic literacy intervention. Unpublished Master of Arts dissertation, University of Pretoria. 
Garcia, O. 2009. Bilingual education in the $21^{\text {st }}$ century: A global perspective. Malden: MA: WileyBlackwell.

Garcia, O. and L. Wei. 2014. Translanguaging: Language, bilingualism and education. London: Palgrave Pivot.

Gqirana, T. 2016. Stellenbosch, Pretoria adopt new language policies (2016.06.23) News 24. http://www.news24.com/SouthAfrica/News/stellenbosch-pretoria-universities-adopt-newlanguage-policies-20160623 (accessed 28 February 2017).

Heugh, K. 2016. Harmonisation and South African languages: Twentieth century debates of homogeneity and heterogeneity. Language Policy 15(3): 235-255.

Hibbert, L. and C. van der Walt. (Eds.). 2014. Multilingual universities in South Africa, Clevedon: Multilingual Matters.

Hornberger, N. H. 2002. Multilingual language policies and the continua of bi-literacy: An ecological approach. Language Policy 1(1): 27-51.

Language Policy of the University of KwaZulu-Natal. 2007. registrar.ukzn.ac.za/Libraries/ policies/Language_Policy_-_CO02010906.sflb.ashx (accessed 17 November 2016).

Language Policy for the University of Pretoria. 2016. http://www.up.ac.za/en/aboutup/article/1900223/language-policy (accessed 17 November 2016).

Language Policy for Stellenbosch University. 2016. Final language policy. www.sun.ac.za/.../ Language/Final\%20Language\%20Policy\%20June\%202016.pdf (accessed 17 November 2016).

Language Policy for the University of Cape Town. 2003. https://www.uct.ac.za/about/policies/ (accessed 12 November 2016).

Liddicoat, A. J. and K. Taylor-Leech. 2015. Multilingual education: The role of language ideologies and attitudes. Current Issues in Language Planning 6(1-2): 1-7.

Lo Bianco, J. 2004. Language Policy and Language Planning handout. University of Hong Kong. Hong Kong. http//:job/hkv-talk-on-lpp/08/12/04

Madiba, M. 2004. Language matters: Parallel corpora as tools for developing the indigenous languages of South Africa. Studies in the Languages of Southern Africa 35(1): 133-147.

Madiba, M. 2014. Promoting concept literacy through multilingual glossaries: A translanguaging approach. Multilingual Teaching and Learning in Higher Education in South Africa, ed. C. van der Walt and L. Hibbert, 68-87. Clevedon: Multilingual Matters.

Makalela, L. 2015. Moving out of the linguistic boxes: The effects of translanguaging strategies for multilingual classrooms. Language and Education 29(3): 200-217.

Makoe, P. and C. McKinney. 2014. Linguistic ideologies in multilingual South African suburban schools. Journal of Multilingual and Multicultural Development 35(7): 658-673.

Maseko, P. 2014. Multilingualism at work in South African Higher Education: From policy to practice. In Multilingual universities in South Africa, ed. L. Hibbert and C. van der Walt, 28-45. Clevedon: Multilingual Matters.

May, S. 2015. Language rights and language policy: Addressing the gap(s) between principles and practices. Current Issues in Language Planning 16(4): 355-359.

Mkhize, D. N. 2016. Resources, mediators, and identities: Home literacy practices of rural bilingual children. Southern African Linguistics and Applied Language Studies 34(1): 43-56.

Moloi, M. and M. Chetty. 2011. SACMEQ III. Trends in achievement levels of grade 6 pupils in South Africa (policy brief number No.1). Southern and Eastern Africa Consortium for monitoring educational quality (SACMEQ). http://www.sacmeq.org/education-southafrica.htm (accessed 8 November 2016).

Mühlhäuser, P. 1996. Linguistic ecology: Language change and linguistic imperialism in the Pacific region. London: Routledge.

Namyalo, S. and J. Nakayiza. 2015. Dilemmas in implementing language rights in multilingual Uganda. 
Current Issues in Language Planning 16(4): 409-424.

Ndebele, N., N. Badsha, B. Figaji, W. Gevers, B. Pityana and I. Scott. (Eds.). 2013. A proposal for undergraduate curriculum reform: The case for a flexible learning structure. Report of the Task Team on Undergraduate Curriculum Structure. August 2013. Pretoria: Council for Higher Education.

Nkosi, Z. P. 2014. Postgraduate students' experiences and attitudes towards isiZulu as a medium of instruction at the University of KwaZulu-Natal. Current Issues in Language Planning 15(3): 245264.

Parmegiani, A. and S. Rudwick. 2014. An exploration of students' attitudes. In Multilingual universities in South Africa, ed. L. Hibbert and C. van der Walt, 107-122. Clevedon: Multilingual Matters.

Pare, P. 2007. The use of local African Languages as languages of science. In The Standardization of African Languages: Language political realities, eds. M. Lafon and V. Webb, 93-120. Proceedings of a Centrepol Workshop March 29, 2007.

Pavlenko, A. and C. Blackledge. (Eds.). 2004. Negotiation of identities in multilingual contexts. Multilingual Matters: Clevedon.

Pennycook, A. 2010. Nationalism, identity, and popular culture. In Sociolinguistics and language education eds. N. H Hornberger and S. Lee McKay, 62-86. Bristol: Multilingual Matters.

Perry, T. 2004. Language rights, ethnic politics: A critique of the Pan South African language board. Cape Town: PRAESA Occasional Papers No. 12.

Phillips, S. 2004. The effects of an intensive reading programme on the academic performance of postMatric English second language students in science. Unpublished MA dissertation. University of Pretoria.

Pillay, V. and K. Yu. 2015. Multilingualism at South African universities: A quiet storm. Southern African Linguistics and Applied Language Studies 33(4): 439-452.

Plüddemann, P. 2015. Unlocking the grid: Language-in-education policy realisation in post-apartheid South Africa. Language and Education 29(3): 186-199.

Roux, J. C. and S. Bosch. 2006. Language resources and tools in Southern Africa. Paper presented at the African Language Association of Southern Africa, Special Interest Group for Language and Speech Technology (ALASA-SIG). 22 May: 11-13.

SA Government News Agency. 2016. Minister dissolves PanSALB Board. SAnews.gov.za. http://www.sanews.gov.za/south-africa/minister-dissolves-pansalb-board (accessed 30 March 2016).

SAIRR see South African Institute of Race Relations.

South African Institute of Race Relations. 1999. South Africa Survey 1999/2000. Johannesburg: Institute of Race Relations \& Centre for Risk Analysis.

South African Institute of Race Relations. 2014. South Africa Survey 2014/15. Johannesburg: Institute of Race Relations \& Centre for Risk Analysis.

Shepherd, D. and S. van der Berg. 2015. Continuous assessment and matriculation examination marks - an empirical examination. Southern African Linguistics and Applied Language Studies 33(3): 78-94.

Skutnabb-Kangas, T. 2006. Language policy and linguistic human rights. In An introduction to language policy: Theory and method, ed. T. Ricento, 273-291. Blackwell: Malden, MA.

Smit, M. H. 2007. Public School Language Policy: Theory and Practice. In. Public School Governance in South Africa, eds. R. Prinsloo and E. Bray, 59-70. Pretoria, Centre for Interuniversity Law and Education Policy (CELP).

Tait, E. 2007. The implementation of an institutional language policy in a multilingual South African higher education society. M.Ed. Dissertation. Central University of Technology.

Turner, N. and R. Wildsmith-Cromarty. 2014. Challenges to the implementation of 
bilingual/multilingual language policies at Tertiary institutions in South Africa (1995-2012). Language Matters 45(3): 295-312.

Webb, V., M. Lafon and P. Pare. 2010. Bantu languages in education in South Africa: An overview akekho, akekho! - the absentee owner. Special issue of the Language Learning Journal, on Language Policy and Practice in South Africa, Part 11. 38(3): 273-292.

Widdowson, H. G. 2001. The monolingual teaching and bilingual learning of English. In New perspectives and issues in educational language policy. In honour of Bernard Dov Spolsky, ed. R. Cooper E. Shohamy and E. Walters, 10-12. Philadelphia: John Benjamins. 